This item was submitted to Loughborough's Research Repository by the author.

Items in Figshare are protected by copyright, with all rights reserved, unless otherwise indicated.

\title{
The implementation of a control system for a product introduction process
}

PLEASE CITE THE PUBLISHED VERSION

PUBLISHER

(c) IMechE / Professional Engineering Publishing

VERSION

VoR (Version of Record)

LICENCE

CC BY-NC-ND 4.0

REPOSITORY RECORD

Backhouse, C.J., Neil D. Burns, and N.J. Brookes. 2019. "The Implementation of a Control System for a Product Introduction Process". figshare. https://hdl.handle.net/2134/4582. 
This item was submitted to Loughborough's Institutional Repository (https://dspace.lboro.ac.uk/) by the author and is made available under the following Creative Commons Licence conditions.

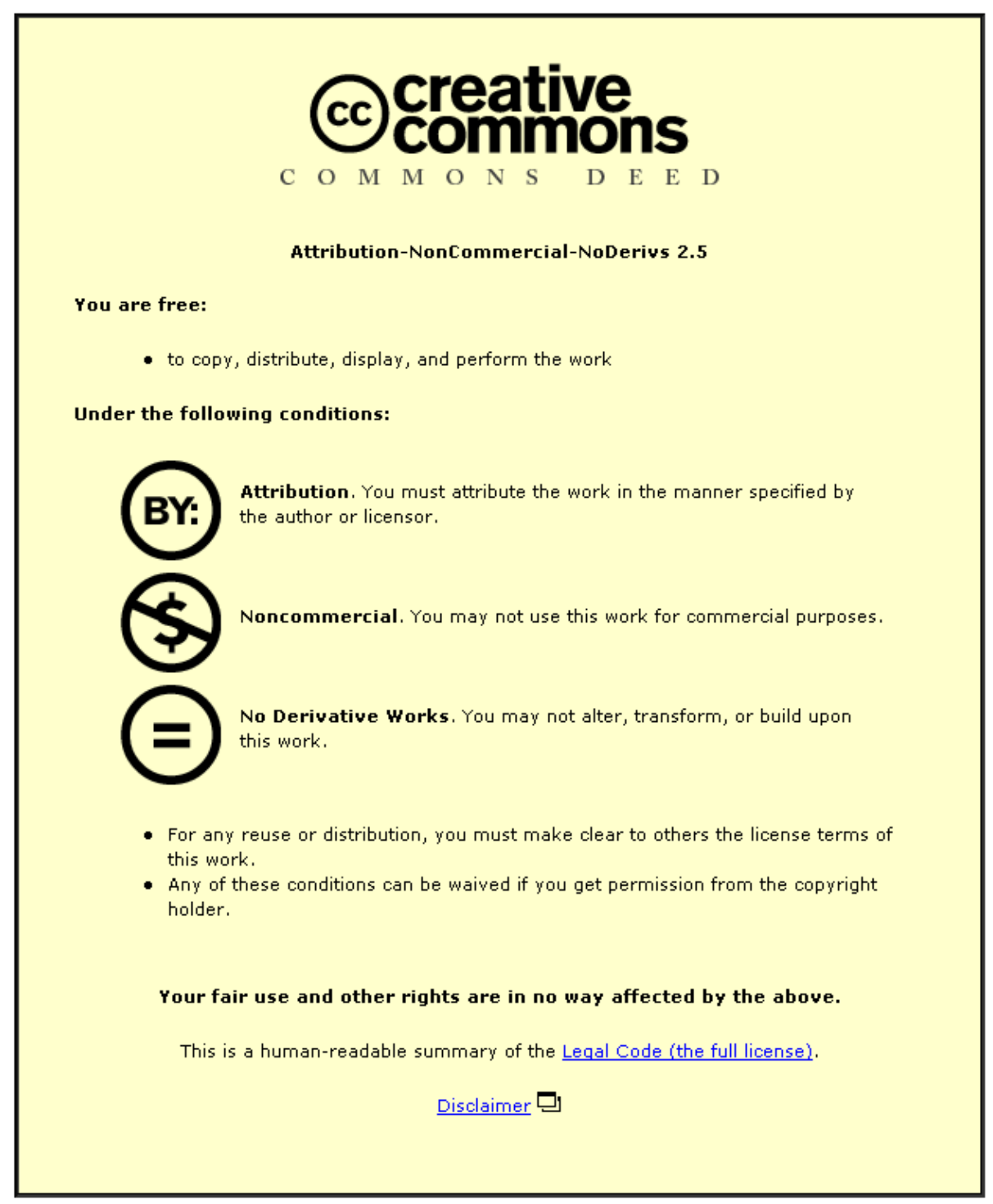

For the full text of this licence, please go to: http://creativecommons.org/licenses/by-nc-nd/2.5/ 


\title{
The implementation of a control system for a product introduction process
}

\author{
C J Backhouse*, N D Burns and N J Brookes \\ Department of Manufacturing Engineering, Loughborough University, Loughborough, UK
}

\begin{abstract}
This paper describes the approach taken in implementing a system to control the new product introduction process in an 'engineering to order' scenario. The primary objective was to ensure that the new system was immediately viable and able to control all aspects of new product introduction, including long-term learning. The approach taken consisted of integrating a series of techniques established by the authors with concepts previously developed in the literature. The consequence of the implementation was a significant improvement in new product introduction performance as measured against company strategic targets in terms of both short- and longer-term priorities.
\end{abstract}

Keywords: product introduction process, concurrent engineering, continuous improvement

\section{INTRODUCTION}

In any restructuring of company activities, involving changes in responsibilities and processes, a very significant challenge is to ensure that new operations achieve target performance as quickly as possible. In the case of the product introduction process (PIP) there are two characteristics which make it a particular challenge to achieve these objectives. The first of these is that, by its very nature, the PIP is a creative process and thus contains an inherent element of uncertainty. While the application of good project management techniques and the utilization of suitable design tools can remove a significant proportion of this uncertainty, there always remains the human element. This human element is fundamental to the provision of high-level conceptual design input, and to ensure its successful application in a business environment it requires suitably subtle control strategies to ensure that targets are achieved.

The second characteristic of the PIP which makes it difficult to optimize is concerned with the time element. This is especially true in the 'engineer to order' environment for the production of large capital plant. Many projects stretch over such a long period of time that it is unrealistic to wait for the completion of the project before applying feedback to improve the process [1]. In order to improve the complete PIP, feedback must

\footnotetext{
The MS was received on 4 May 1999 and was accepted after revision for publication on 18 November 1999.

* Corresponding author: Department of Manufacturing Engineering, Loughborough University, Loughborough, Leicestershire LE11 3TU, $U K$.

B03799 (C) IMechE 2000
}

therefore be staged and based upon intermediate performance measures. Although this approach, implemented by the vast majority of companies, ensures that staged targets are set and monitored, the performance of the PIP in the late 1990s is now so critical to company performance that in many instances the time-scale of even this level of feedback is unsatisfactory. The recognition, at an intermediate stage, that the PIP is not operating in an optimal manner can occur too late for a company to ensure that it achieves its product launch date. Due to the intense time pressures, identification of delays at intermediate stages does not necessarily mean that remedial action can be successful in putting the project back on schedule. There is a requirement for continuous feedback which allows for optimization of both the project itself and the underlying process.

The difficulties involved in controlling and ensuring continuous improvement to the PIP are compounded when a company instigates a radical restructuring of operations involving changes to structures and processes. Although certain elements of best practice can be re-incorporated into restructured processes, there will always be the requirement for completely new process strategies to be implemented. In restructuring operations a company is faced with a significant challenge in instigating change to the PIP, one of its most crucial processes for long-term business performance.

It was the aim of ensuring that any restructured PIP had all the characteristics necessary to guarantee performance from the start of implementation that led the authors to follow the course of action described in this case study. The approach consisted of developing a PIP 
structure and control system using an integrated set of techniques which ensured that the PIP was immediately viable, both in terms of providing short term feedback to improve performance and longer term opportunities for corporate learning. The approach taken by the authors was to employ the concept of developing the new PIP as a 'viable system', a concept developed by Beer in his viable systems model (VSM) [2], and to combine this with concepts of concurrent engineering (CE) and Nissan green areas (GAs).

The development of the new PIP was driven by the company's strategic objective of improving customer service by reducing project lead times and product costs while improving delivery reliability. It was recognized that the concepts of CE were basic to the achievement of these objectives, but that the form of CE adopted would have to be tailored to the particular circumstances of the company. This tailoring of CE was based upon concepts previously developed by the authors [3] which had recognized the contingent nature of CE implementations.

The organizational changes that resulted were based upon the recognized concepts of moving away from a conventional, functionally based structure to one based around teams. However, the key change to the organization was not simply the structural change from a functional to a project-based approach. This would not have been successful if carried out in isolation from the development of new methods for short-term project control and long-term organizational improvement. It was the control system which overlaid the new organizational structure that effectively ensured success for this reorganizational activity. The central aspect of the new control system was the application of the concept of the Nissan GA [4]. This visible approach to team and project monitoring was implemented in such a way that it became the fundamental control system for the PIP, satisfying the needs for both short-term project control and longer term improvement.

\section{BACKGROUND TO THE RESTRUCTURING}

The subject of this case study is a division of an East Midlands company involved in the design and manufacture of heavy duty cranes up to a capacity of $250 \mathrm{t}$. The division operates on an 'engineer to order' basis and has an order winning criterion of being able to incorporate specific customer requirements into standard designs while maintaining quality, price and delivery reliability. Orders are received as a consequence of competitive tendering based on outline designs. A high risk element of the process concerns late delivery penalties, which can be extremely substantial and can quickly turn a profitable contract into one which generates significant losses for the company. The design and manufacturing activity from the time of the contract being awarded to the crane arriving on site typically runs from between six months to one year for a single contract, with contract values typically lying in the range of $£ 2 \mathrm{~m}$ to $£ 12 \mathrm{~m}$.

Due to increasing world competition and the shortening of customers' planning horizons, the pressures on the crane industry have been to reduce cost while significantly shortening lead times. The company quickly came to recognize that both its structure and internal controls were no longer appropriate to match the external market requirements and that the concepts of $\mathrm{CE}$ had to become a central part of the PIP. A process of change was therefore instigated and was based on driving change in structures and processes through a recognition of market forces.

\section{TRANSLATING MARKET FORCES INTO A CHANGE PROGRAMME}

The pressures for change within the company can be placed in context by reference to the well established concepts developed by the management theorist Henry Mintzberg [5]. In the late 1970s he developed a simple, graphical method of describing the effect of market forces on the characteristics of a company. This is shown in Fig. 1 and comprises a pentangle of company types developed as a consequence of the market forces acting on them. The market forces are defined by the terms: direction, efficiency, concentration, learning and proficiency. The forms that a company may take up as a response to the market forces are described by the terms entrepreneurial, machine, diversified, innovative and professional.

This model has been recognized as providing a simple but very valid description of how companies develop their structures to match market requirements. In recent years many companies can be seen to have responded to the market forces of reducing costs and improving service quality (i.e. responding to the force of efficiency) by adopting a machine-type structure. This structure is characterized by a series of focused operations with minimal support infrastructure, i.e. a lean organization.

However, many companies operate in a market which is characterized by the demands of customers who are looking not just for the benefits of efficiency but also for a demonstrable level of expertise within a company. This requirement is necessarily present in the crane industry, where customers seek a high level of confidence that the supplier actually has the technical skill to satisfy the needs of the contract. Under these conditions the market is applying a force for proficiency (as defined by Mintzberg) resulting in the need for a professional form of organization. In the case of the company reported in this case study, the forces of efficiency and proficiency are therefore acting and the proposed restructuring would have to satisfy both these requirements. To satisfy 


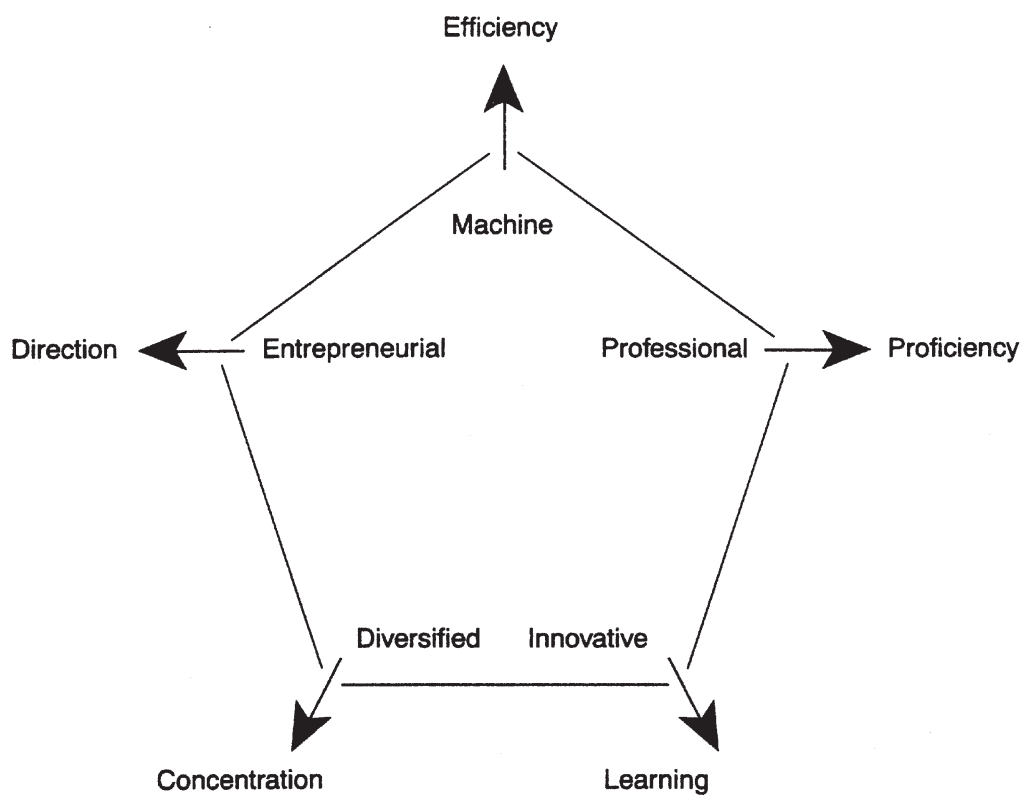

Fig. 1 Mintzberg's model of forces acting on companies and the forms they consequentially adopt

efficiency requirements indicated a control system which operated on a short time-scale, while proficiency indicated a longer term view for skills development and institutional learning.

In many circumstances the forms of company most suited to satisfying the requirements for proficiency and efficiency are contrasting and not mutually supportive. The professional form has traditionally been typified by a functional organization split between skill types, as indicated in Fig. 2a. This structure was, in the past, seen as the most suitable for retaining and developing skills, but it is not the most responsive to the market pressures of efficiency. The functional organization finds it difficult to cope with a situation where the market demands reduce lead times and lower prices. In some situations it is possible to overlay the functional organization with project coordinators, as shown in Fig. 2b.

However, the reality of the situation is that the project coordinators may not be sufficiently powerful within the organization to achieve the set targets. As a consequence, the requirements for efficiency drive a company to take

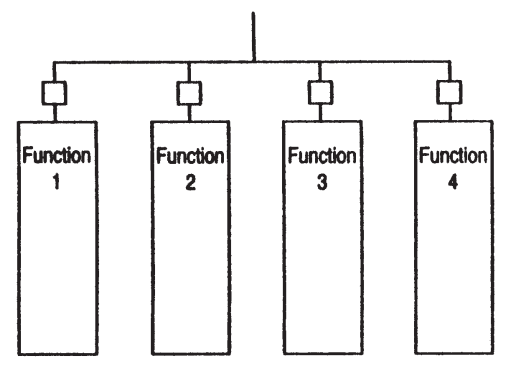

(a) Functional

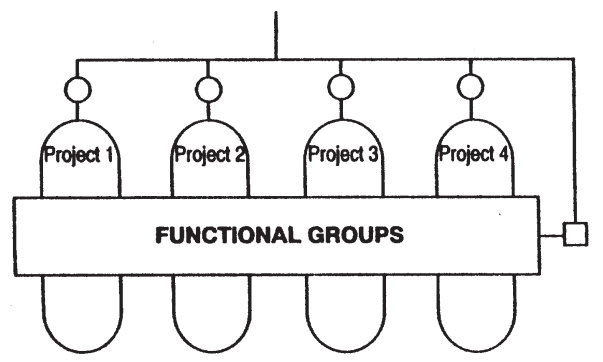

(c) Heavyweight project management

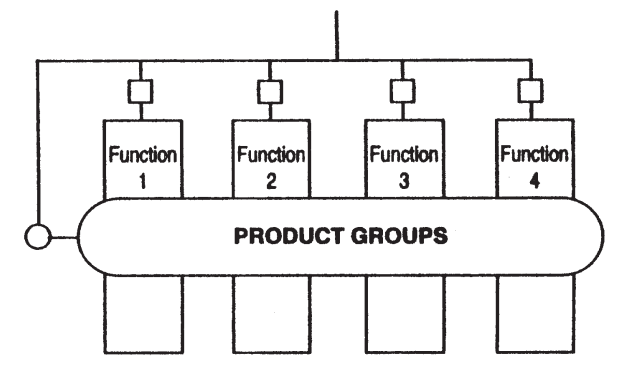

(b) Lightweight project management

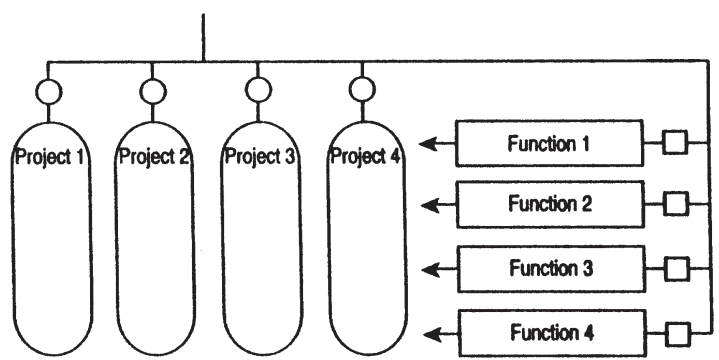

(d) Dedicated project teams

Fig. 2 The various organizational structures that companies can adopt 
on a machine-type form based upon multiskilled project teams which are typified by the structures shown in Figs $2 \mathrm{c}$ and $\mathrm{d}$. These provide the necessary strength of control to ensure that project targets are adhered to. However, they do raise problems associated with long-term learning and skills retention, issues which the functional organizations were well able to ensure. The challenge for the company described here was to instigate a process of change which preserved the best features of a professional organization and ensured that the benefits of a machine-type form could also be incorporated into the company.

\subsection{The change programme}

Once the challenge had been identified, the next stage in the process was to consider the actual changes that were required. In this respect the diagram shown in Fig. 3 and previously developed by the authors [6] is used to describe the activity. This diagram is effectively a subset of the one developed by Mintzberg but considers only the PIP. It aims to enable the introduction of CE in a form contingent on the particular circumstances of the company concerned. The diagram considers the forces acting on the PIP and identifies them as: efficiency, proficiency, radical innovation, incremental change and focus.

While the forces acting on the PIP have their equivalents in Mintzberg's higher level diagram, the similarity ends there. In contrast to Mintzberg's diagram, the inside of the pentangle is occupied by the well established set of elements comprising an organizational system, i.e. structure, process, tools, control and people [7]. These elements, represented as lying on a disc, depict the common experience of changing the priorities for improvement based upon one or more of these elements in turn, often following a repeated pattern. The focus moves round until, after a period of time (usually several years), the same elements become the focus of attention again. The important feature to recognize is that, while the improvement cycle is ever-repeating, the improvements themselves are cumulative and can be represented by the commonly depicted upward spiral of improvement.

Within the case study company it was quickly identified that, of the five system elements, those of people and tools would not be the focus of this new initiative. Ongoing and recently completed initiatives had already addressed these areas. Skilled people, both in terms of technological and project management capabilities, were either in place or being recruited. Similarly, the CAE systems were working well and were appropriate. However, the functional-type structure and the processes it encouraged were quickly identified as a barrier to satisfying the new market requirements. These had to be changed but, at the same time, the benefits associated with skill retention and development which the existing structure encouraged should not be lost. The issue of control, and specifically that of ensuring products were designed and manufactured on time, was seen as a shorter term issue interacting with the longer term issue of individual and institutional learning necessitated by the requirement for proficiency in this 'engineer to order' environment. Therefore, while it could be readily identified that changing the structure to a more project-based approach could provide certain

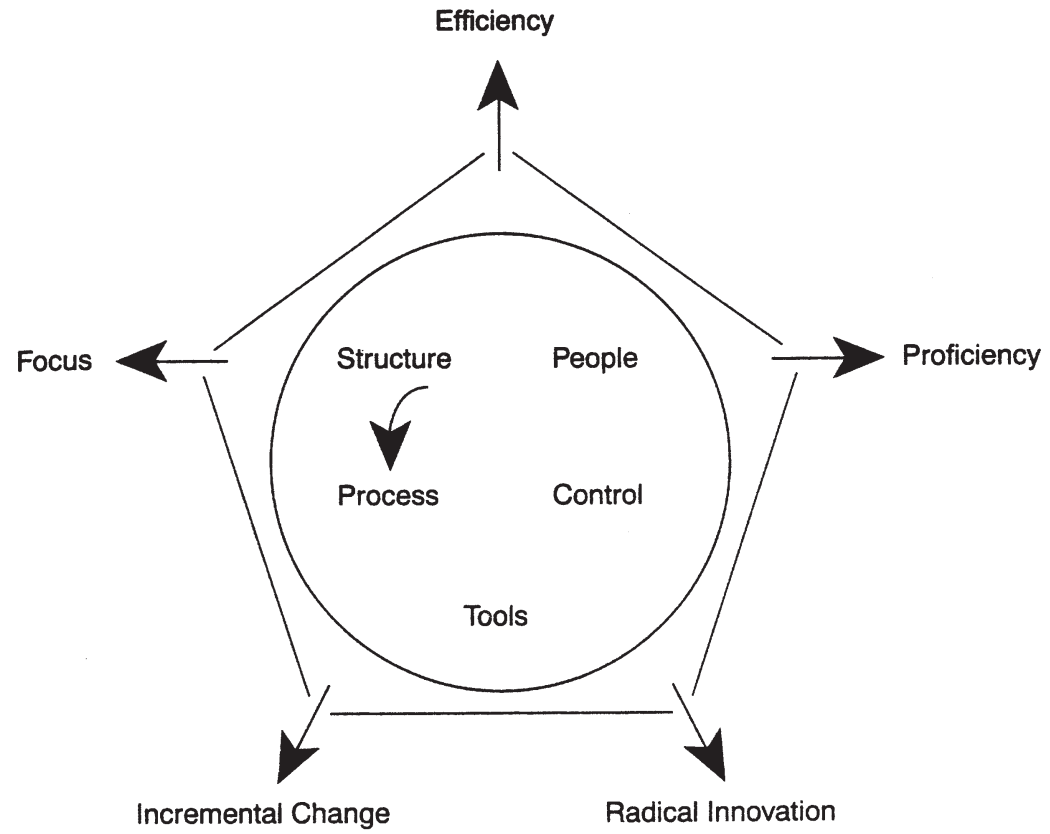

Fig. 3 Forces acting on a PIP and the form elements 
benefits in terms of reduced lead times, ensuring that previously successful issues were not diluted was seen as a control issue.

At this stage in the restructuring the philosophy of the company impinged on the chosen solution since the view in the company had evolved into one where, whenever possible, control systems would be immediately visible, accessible to all, and simple. The approach of Nissan and their application of GAs had long found favour in the company at shop-floor level and it was now decided that this approach would be utilized to form the basis of the control system for the PIP. With this agreed, the aim then became to develop the overall PIP control system such that it provided all the necessary monitoring systems, while ensuring that it minimized the need for record keeping. This dual objective was to ensure that the core activity could be controlled successfully but with a minimum of effort on the part of those involved.

This approach of developing a minimal control system does carry the inherent risk that certain aspects of the system may be initially overlooked or omitted. To ensure this did not happen, and as previously mentioned, it was decided to utilize the concept of Beer's VSM. As will be seen in following sections, this approach provided the link between the restructuring process and the successful implementation of the visible control system.

\section{PLANNING THE CHANGE}

The first stage in developing the plans for changing the PIP was to carry out a conventional SWOT (strengths, weaknesses, opportunities and threats) analysis in order to fully identify present and future company capabilities and market requirements. It was the SWOT analysis which identified that, in order to compete successfully in the field of crane design and manufacture, the future vision of the company rested on its ability to match the market requirements of shorter lead-times, lower cost and on-time delivery, while aiming to offer improved products with the potential for greater added value.

The main market qualifiers necessary to remain as a viable competitor in the market in the short term were clearly associated with the time and cost criteria. These became the primary drivers in developing the new PIP, both in terms of its structure and control system. The secondary driver was associated with the need to offer products with improved functionality which would inherently be based upon long-term design skills development. Thus, although the restructuring was primarily driven by concepts involving efficiency, the changes were always carried out with longer term improvement fully in mind.

Prior to the restructuring the design activity was primarily functional and departmental based, with each function being based around the core skills. One depart- ment would contain mechanical designers, another electrical designers and another technical support, such as finite element analysis. The functional arrangement in the design office resulted in the work packages associated with a contract being moved from function to function, with each department designing their part of the contract almost independently. This method of working led to the usual problem of lack of communication, with the consequential design inefficiencies and errors. Undoubtedly the underlying approach that was required would involve a CE implementation which moved away from this functional approach and adopted a more customer-focused team-based concept.

Following a detailed appraisal of activities within each of the various functions, a proposal was developed to introduce cell-based operations within all the elements of the PIP. This would involve all personnel from the managing director down, since the PIP is a fundamental process of the company involving all levels of activity. The managing director would become part of a strategic cell, design staff would form design cells, while operational cells - already in existence-would complete the structure. At the design level cells were created around product types, for example ship-to-shore cranes or steelworks cranes. However, the approach was sufficiently flexible for cells to be established upon a geographical region where it was considered to be a major market and beneficial to demonstrate synergy between projects.

\section{GA PERFORMANCE MEASUREMENT}

The company had experience with visual control systems within GA operation cells and this experience was put to good use as the concept was developed throughout the business. The primary nature of GAs is to provide immediate measurement of performance against targets. The company's experience in implementing GA operational cells had resulted in a range of factors that would be included in each cell, combined with a set of cell-specific measures based upon a common philosophy.

Certain measures related directly to the performance of the cell team as measured by the team itself, such as adherence to schedule, cost versus budget, wastage rates etc. A second set of cross-measures was generated by those cells which acted either as the customer or supplier cells to the original cell. Skill and training records formed a third set of measures and, finally, the cell members were free to develop a set of measures at their own discretion. This final set of measures usually comprised the number and detail of improvements generated by the team.

The cross-measurement system developed by the interrelationship of customer and supplier cells was of fundamental importance to the success of this approach since it ensured that cells did not become too inward looking and develop measures which, while putting the best light on 
their performance, might not be the optimum for overall company achievement. It provided an impartial view of the cell's performance, with the quality of the service into and out of the cell being monitored visually and providing the necessary information for local control.

\subsection{GAs applied to product design}

The company recognized, from the experience it had developed in operating GAs at shop-floor level, that this approach to control could be utilized throughout the business. In particular, the challenges faced by those personnel directly involved in the design of new products were recognized as being highly suitable for the implementation of GAs. The potential benefits of providing immediate visual measures integrated across the business were in both the short-term process improvement area and the longer term area of capability improvement.

Although there was a standard requirement for certain measures that should be displayed, team members were given considerable discretion in designing the displays and setting up their own GAs. Each team decided on a name for their area, arranged their displays and kept them up to date. A diagram showing a typical GA display of measures is shown in Fig. 4. Every cell had several displays: an attendance register which logged the cell members' presence at a meeting at the start of the working day, a skills register which showed skills and training, relevant local and cross-measures, and improvements generated by the cells.

One of the most significant displays in the design teams' GAs was that of skills and training. A multilevel scheme was developed to provide measures varying from the highest level of fully professional in a particular skill, to the lowest level of being 'in training'. This was primarily applied in the design cells, where each level was validated by a testing scheme administered by senior Chartered Engineers in the business. Specific professional skills, for example 'structural engineering', were then graded for each individual. At the start of each contract planning process the contract managers made an assessment of the skills needed to complete the contract and matched this to the availability within the cell, initially, and then the business. This enabled them to define their optimum contract team structure, and the desired cell membership. They could also define any training requirements needed to complete the contract. The commitment to skills development and the recognition of capabilities strongly supported the parallel, ongoing company activity of recruiting a new generation of highly qualified Chartered Engineers. In a business environment of high mobility for wellqualified, experienced engineers, this strong commitment was recognized as supporting the retention of good people. Thus, the initiatives reported in this paper not only directly supported the improvement of the PIP

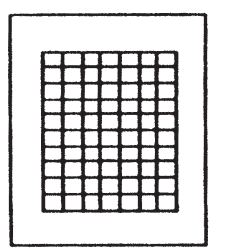

1. Skills Matrix

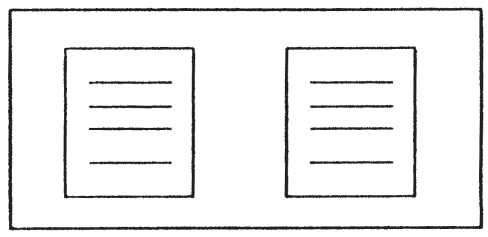

5. General Green Area Messages

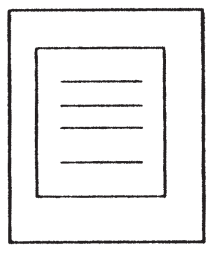

10. Strategy Team Summary

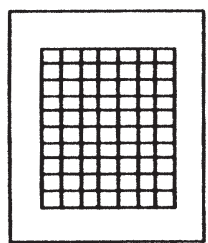

2. Training Plan

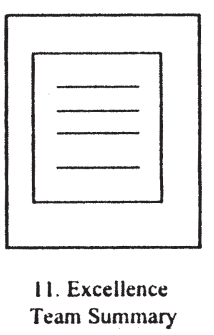

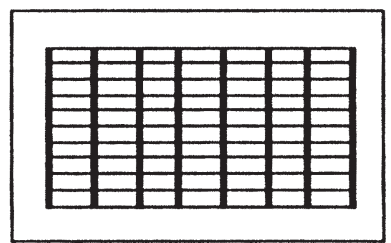

3. Attendance Matrix and Team Member Photographs

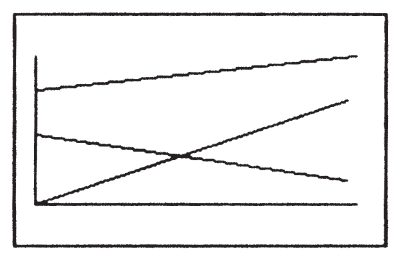

6. Performance Measures

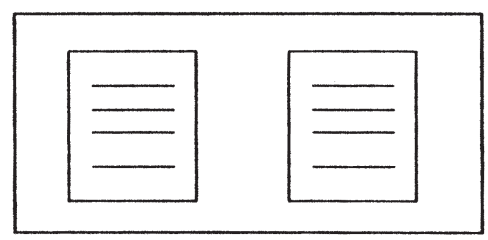

12. Improvement Requests to/from other teams

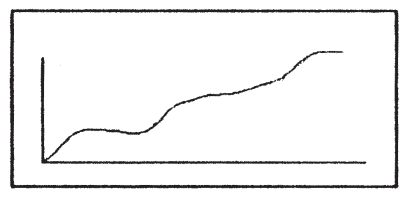

4. Quality Performance Chant

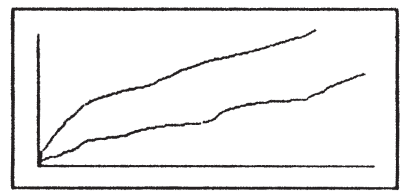

7. Performance Measures

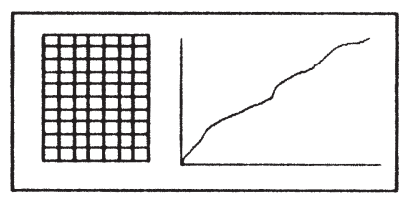

8. Cross-Performance Measures

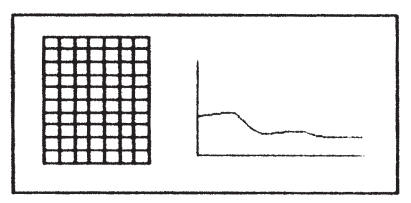

9. Cross-Performance Measures

Fig. 4 Typical GA display of measures 
but also had a direct influence on supporting other ongoing improvement activities.

In each design cell there was to be a core cell team membership, consisting of a project manager and a senior mechanical engineer. The project manager had basic responsibility for crane production, which was effectively measured by the ability to meet the full customer specification within the time and cost constraints defined in the original tender. The senior mechanical engineer was responsible for the technical aspects of the crane design and manufacture. The remaining cell team membership was dynamic in that it was dependent on the contract skill needs. These people were hired into the contract team from a technical support cell. The cellbased system for the design area formed an integrated scheme linked directly with the cells in other parts of the business.

\section{COMPANY STRUCTURE REDESIGN}

The restructuring of the company was based upon the development of GA cells at all levels in the business. The relationship between the cells was determined by the previously described concepts of Beer's VSM, combined with a mechanism for continuous improvement to operations. The VSM is based upon five levels of
Table 1 The elements of Beer's VSM

\begin{tabular}{ll}
\hline System 1 & Operational activity \\
System 2 & Operational coordinating activity \\
System 3 & $\begin{array}{l}\text { Operational management control system } \\
\text { Rapid auditing channel enabling system } 3 \text { operational } \\
\text { managers to quickly determine the performance of } \\
\text { operational system }\end{array}$ \\
$\begin{array}{l}\text { External environment scanning subsystem } \\
\text { System } 4 \\
\text { System 5 }\end{array}$ & Strategic level \\
\hline
\end{tabular}

control and can be used as a foundation for ensuring that a control system is complete and is therefore 'viable'. A viable system, as defined by Beer, is based upon a hierarchy of system elements which together ensure that all the basic requirements for overall system control are in place. The system elements are listed in Table 1.

The foundation for change within the case study company was fundamentally based upon the VSM. The complete business was remodelled to ensure that all existing functions were included, with none being allowed to be 'outside' the new structure. The new company structure is shown in Fig. 5, which shows the interrelationships of the various system levels of the VSM. It can be seen how the operational GAs were established as system 1 and then interacted with system 2 operations coordination and system $3^{*}$, the audit channel. Further detail

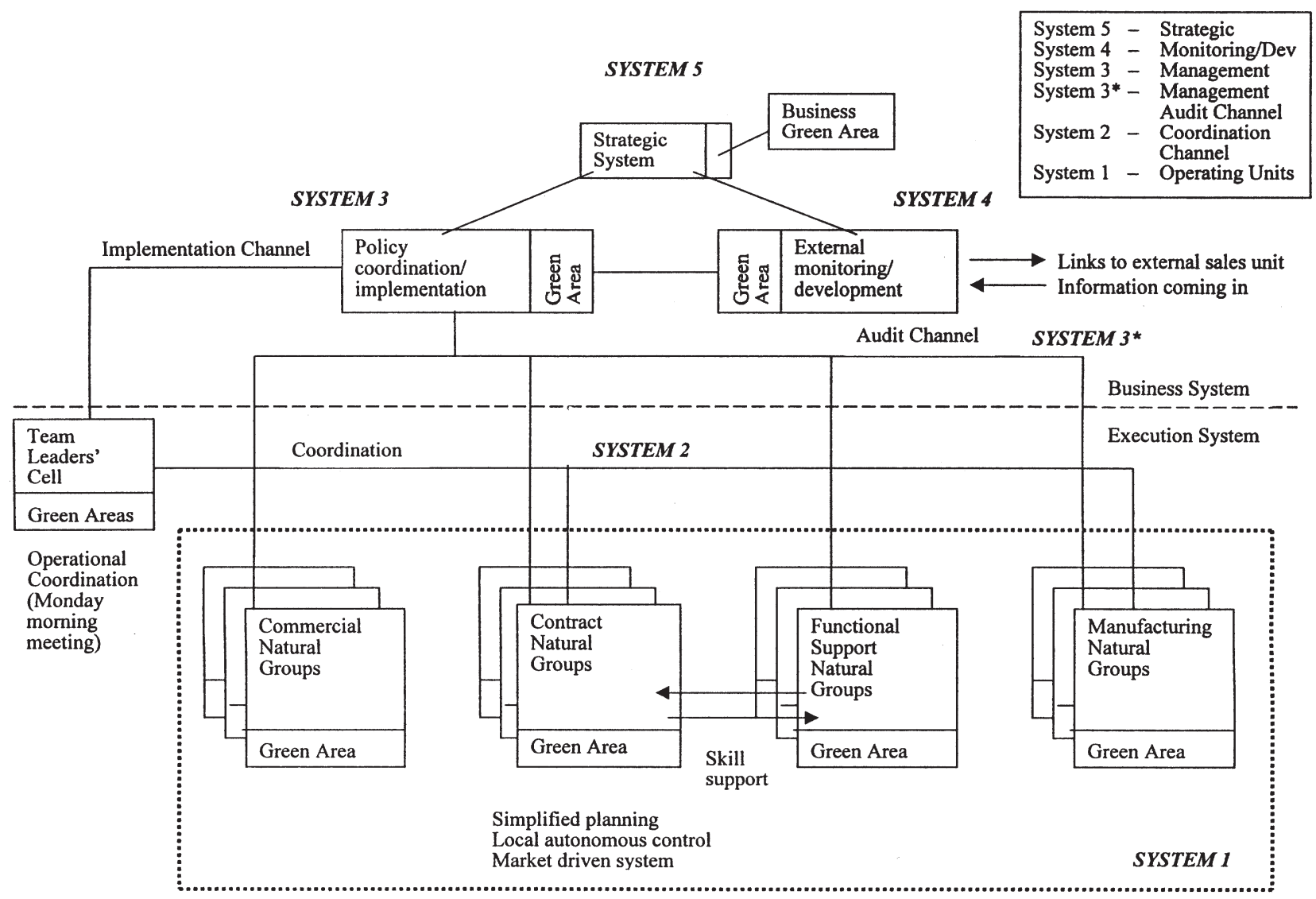

Fig. 5 Company structure based upon the VSM 
and the relationship between each of the levels of the VSM are described in the following sections.

\subsection{Operation level-VSM system 1}

GA teams which already existed at design and shop-floor levels were modified and, where relevant, expanded to encompass technical support, administration, purchasing and accounts. At shop-floor level the GAs had already reached a satisfactory level of sophistication and therefore little change was required. However, significant change occurred in the design office, where the most effective change was found to be the inclusion of purchasing managers within GAs. These managers became full-time members of one GA for the duration of the project. With the inclusion of all personnel having a direct influence on the contract delivery in the GA team the lines of communication were drastically reduced, resulting in reductions to both lead times and contract costs.

These GA teams, being the operational activity of the company, corresponded to system 1 of the VSM. Each GA was a self-contained unit with local measures directly appropriate to its work and supported by other displays, which included such measures as attendance and skills that were present in the cell team. Their structure and visual measurement of performance were designed to facilitate the implementation of the rapid auditing of performance by operational managers. As described in Section 6.3, the operational managers correspond to system 3 of the VSM and the rapid auditing channel corresponds to system $3^{*}$ of the VSM, described in Section 6.4.

\subsection{Operations coordination-VSM system 2}

In order to ensure coordination of operations across the business, the team leaders of each operational cell would meet together at the end of each working day. This meeting would typically be fairly short, but would enable team leaders to brief each other with regard to any relevant developments which applied across a number of cells. This information could then be fed back into the individual GA morning meetings by the team leaders. This approach to operations coordination satisfied the requirements of system 2 of the VSM in that it ensured rapid feedback for issues raised and a method of transferring this information back to interested parties who could then act to ensure full operational coordination.

However, of particular importance was a second level of coordination that was implemented. The objective was to put in place a system which would enable the coordination of continuous improvement at operational level. This was achieved by overlaying onto the operational system new GA cells known inside the business as 'excellence cells', a term adopted by the senior management.
They were named 'excellence' because they were intended to make a major contribution to business improvement by implementing major changes and long-term developments. The membership of the excellence teams was made up from the operational GA team leaders, people drawn directly from the operational teams, and others from support teams with expertise appropriate to the improvement projects being considered at that particular time.

Attached to each excellence cell was a facilitator or change agent who acted to implement some of the more complex improvement projects that required the participation of several operational cell teams. Typical projects would be the introduction of new business IT systems or new computer-based analysis and design tools. The excellence cell system acted as a second integrating and coordinating layer around the system 1 operational cells in addition to the daily meeting of operational cell team leaders. One of its roles was to ensure that ideas generated in one cell were passed to all the others; hence enabling an organizational learning role.

The combination of daily meetings of operational cell team leaders and fortnightly excellence cell meetings ensured that the business operated with a unified purpose in meeting both the immediate operational targets and the longer term strategic improvement objectives.

\subsection{Operations control-VSM system 3}

The operational management of the design activity met on a weekly basis with all the cell team leaders to review project progress, work-loads and status of new contracts. This effectively formed the system 3 level of the VSM. Work-loads for the operational cells were defined and any changes to overall strategy developed by the strategic cell team (see Section 6.6) were disseminated with action plans developed. The operational management had ready access to information about performance via the display boards in each of the operational GAs. The link between this level of operations control and the strategic objectives of the business was through the divisional manager who led the system 3 GAs and sat on the system 5 GA, which in turn was led by the company's managing director (see Section 6.6). This then formed the link between the system 3 function and the strategic system 5 function.

\subsection{Operations feedback-VSM system $3^{*}$}

At the start of the working shift, in each operational cell, there was a meeting to consider work problems, training and cell improvement issues. Part of the GA contract agreed by all the personnel in the business was that if any issue raised by a team member could not be answered by the team leader or other team members, 
then a notice was to be placed on the GA board. Senior managers, being members of the strategic team, were required to regularly monitor the boards and to respond within 24 hours. The display boards in each GA, together with the requirement for a quick response by senior management to issues raised by operational cell team members, met the requirements of system $3 *$ (the audit channel) in the VSM.

\subsection{External environment scanning-VSM system 4}

As previously described, the excellence cells were established as an overlay to system 2 (operations coordination). However, the excellence cells also took on the role of forward looking, which effectively formed system 4 of the VSM. The implementation of this arrangement brought together the activity of identifying future needs with the activity of implementing these needs. The excellence teams were responsible for identifying and implementing improvement to both the product introduction process and the products themselves. To do this they had to have links with all the other systems and in addition to the outside world, particularly in terms of customer trends and competitor actions. Based upon this knowledge, they were able to define the improvement projects needed in their domains. They would then make their case to the strategic cell team, which would then prioritize in relation to overall business strategy and availability of resources. The excellence cell team would then plan and coordinate implementation of projects with results being registered in the excellence GA.

\subsection{Strategic-VSM system 5}

The purpose of the strategic cell team was to determine business direction and strategy and to ensure that the defined set of objectives was implemented. The members of the strategic team were the business leaders, representatives from sales and marketing and team leaders from the various excellence cells across the business. The strategic team was led by the managing director and developed its own set of visual measurement systems in the same way as all other GAs. The strategic cell formed system 5 of the VSM.

\section{IMPLEMENTATION}

It should be clearly recognized that this implementation was achieved via a very pro-active and directive management approach. The concept of participation was fully encouraged at the level of designing individual GAs, but the overall policy was determined and imposed by company senior managers. Detailed planning of the new company structure was neither a short, nor incon- siderable, activity. Over a period of approximately six months a team of three senior personnel, working on average two days per week, mapped out the complete organizational structure based upon the VSM from the system 5 level down to the system 1 level. This included considerable discussion and consultation with personnel at all levels in the company.

In terms of implementation, there was relatively little cost involved in creating the new structures and setting up the GAs. Indeed, the implementation process was completed very quickly, over a period of two weeks. Some rearranging of office layout was required to colocate team members but this was not universal. In some instances, and where it would have no detrimental effect on performance, it was decided to retain the staff in their functionally based locations.

The process of ensuring that the GAs functioned as intended can be divided into the short- and long term. In terms of satisfying the need for control of product introduction, the GAs immediately provided the necessary source of information and feedback for projects to be progressed more effectively. However, the concept that the GAs could be used for encouraging the longer term issues related to skills and capability improvement required that staff underwent training in order to see the full benefits of the new system and how to operate within it. Initially, champions were identified and these people took the lead part in promoting the change in working practice that enabled the GA concept. These champions typically went on to become team leaders.

The most challenging issue with regard to implementation related to the cross-measurement system. People could be reluctant to put formal measures on the display about the performance of their supplier or customer cells. Cross-measurements were used when there was a strong interdependence between teams, i.e. there was a supplier-customer relationship. An example of this was employed to illustrate the performance of accounts and purchasing functions serving the design teams. Although used extensively, human nature did tend to limit, to some extent, the speed of implementation of cross-measures. However, to a large extent the excellence GAs had, as one of their roles, the ability to compensate for any shortfall in cross-measures. The excellence GAs took their instructions from the strategic GA and implemented major improvement projects in the business. They met every two weeks and allocated resources to complete projects such as implementing business systems and transforming the company into a paperless organization. The projects were planned and controlled, with regular feedback of progress being presented to the strategic GA for assessment of progress and reprioritization of projects.

Change agents were allocated to each excellence GA to act as team leaders to the implementers and drivers of change. The change agents were specifically recruited as young, recently graduated engineers who combined 
both technical and management capabilities which would ensure change was driven through any obstacles which may have been encountered. This approach to implementing change enabled the company to simultaneously restructure its graduate recruitment and training scheme. The high profile generated by the recruitment of highly motivated change agents encouraged further recruitment of specialist engineers into specific design areas fundamental to the technical improvement of the products.

\section{IMPROVEMENTS TO THE PIP}

The structural change in the design activities was achieved within a matter of days, with some preliminary effects in terms of quality and ease of communication being seen immediately. The introduction of the cellbased system provided team members with direct, local and visual control over their own performance. Highlighted issues immediately became the focus of team discussions and led to an obvious increase in communication between the various personnel employed within the team. Since all the cells were located within the viable system hierarchy, with project objectives being derived directly from the strategic cell, the measured performance was always fully aligned with the strategic objectives of the company.

Almost immediately individuals were commenting that they were communicating on a more regular basis, with a greater quantity and quality of information being transmitted within the team. Most noticeable was the speed with which the new structure 'bedded-in'. The extensive period spent planning the changes and the focus on including all activities within a VSM approach reaped the desired benefits in achieving a structure which was effective from the start. Any areas of uncertainty or lack of clarity in terms of information flows were caused simply by the learning curve requirements of individuals. However, the clarity and simplicity of the new VSM-based structure combined with the GA displays meant that, for most people, familiarity was achieved within a matter of days.

At the level of team interaction the lines of communication became much more clearly defined being based, as they were, around the VSM concept. Lines of communication between design teams and manufacturing teams were not only simplified but, through the VSM approach, were ensured to be appropriate. At VSM system 1 level, design team members had clarity of information flow with other teams involved in manufacture and at VSM system 2 level, the daily meeting of team leaders ensured coordination of activity in support of targets disseminated through the company from the VSM system 5 level. Unquantifiable (at that stage), but very clear, were the benefits obtained from this clarity of information flow and the absence of 'noise' which was previously created in the company through the inappropriate interaction of information flows at strategic and operational level. The VSM approach ensured both the appropriateness of information and the efficiency of its transmission.

\subsection{Early measurable improvements}

After approximately three months, when some smaller product development projects had been completed, the benefits began to be identifiable in a more quantifiable way. Contract completion dates started to improve, with delivery dates being hit in a more reliable manner. Costs began to reduce as better coordination between the various design, purchasing and manufacturing activities resulted in reduced parts and manufacturing costs. After approximately six months there was a high level of confidence that the benefits obtained were consistent and maintainable. In addition they were now becoming measurable, as can be seen in Table 2 which highlights some key improvements measured in a challenging environment where customers were demanding ever improving performance.

Table 2 Measured improvement in performance

\begin{tabular}{|c|c|c|}
\hline & $\begin{array}{l}\text { Averaged previous contract } \\
\text { (sample size, eight contracts) }\end{array}$ & $\begin{array}{l}\text { Averaged new contract } \\
\text { (sample size, five contracts) }\end{array}$ \\
\hline \multicolumn{3}{|c|}{ Short-term measurable improvements } \\
\hline 1. Cost control of the contract & $20 \%$ overrun on each contract & $10 \%$ overall reduction in costs \\
\hline 2. Labour costs & $30 \%$ overrun & $10 \%$ reduction in labour costs \\
\hline 3. Purchased parts & $10 \%$ overrun & $20 \%$ price control reduction \\
\hline 4. Time for contract completion & $\begin{array}{l}10 \% \text { overrun on an averaged contract length of } \\
\text { one year }\end{array}$ & $\begin{array}{l}\text { Within average estimated contract length } \\
\text { of } 9 \text { months }\end{array}$ \\
\hline \multicolumn{3}{|c|}{ Longer-term indications of continuous improvement } \\
\hline 5. Global operations & Permanent presence in only two countries & $\begin{array}{l}\text { Global business with permanent presence } \\
\text { in all continents }\end{array}$ \\
\hline 6. Service business & No product service business & 13 service businesses in the UK \\
\hline 7. Qualifications of personnel & Only three members of either the IMechE or IEE & $\begin{array}{l}20 \text { members of either the IMechE or IEE; } \\
\text { three PhDs and many staff with MScs }\end{array}$ \\
\hline
\end{tabular}


Prior to the restructuring, typical contracts were seen to run over cost by approximately 20 per cent of target cost. Following restructuring, actual costs were reduced by 10 per cent as measured against previous target costs - although it should be noted that customer price pressures were constantly driving down target costs and actual cost reductions were only just keeping pace with price reductions. As an element of total cost, labour cost achieved the greatest improvement, moving from a typical 30 per cent overrun on target to 10 per cent below original targets. This was achieved by a combination of reducing overall designed-in labour and minimizing rework costs through much improved communication at the design stage. Purchased parts costs also saw a significant reduction, from a 10 per cent overrun to a 20 per cent reduction on original targets. Improved cooperation between designers and purchasers at the design stage enabled tighter specifications on purchased parts to be made, combined with an improved approach to design trade-offs within the design activity facilitated by the improved communications. Overall, contract completion reduced from an average of 12 months to 9 months, with projects completing on time as contrasted to the previous 10 per cent overrun on time.

\subsection{Longer term improvements}

The short-term improvement in terms of projects being completed on time and to cost became obvious as time progressed. As predicted, the design of the cellularbased control system based around the VSM ensured that it was complete and came on stream in a rightfirst-time manner. However, there was an equally important target of achieving a culture of improvement in the longer term which would continuously act to enhance the PIP. As described in Section 1, the ability to measure the effect of such an improvement culture can be problematic due to the long-term nature of the 'engineer to order' business. However, secondary measures which, while not directly assessing improvement, do provide an excellent window on an improvement culture, are achievable and were monitored by the company. These were in addition to the shorter term, and quantifiable, measures described in Section 8.1.

The measures chosen to evaluate the effectiveness of the new PIP were derived directly from the strategic objectives of the company. The measures were evaluated to see how the new structure for the PIP supported these strategic objectives, in contrast to those objectives achieved by the new PIP structure and described in the previous section. The results are shown in the bottom section of Table 2 .

The major strategic priority for the company was to develop from a UK identified business into a global player. Several enablers were already in place through distributor networks, local agents and support from the US parent. However, the primary inhibitor had long been the ability of the company to respond quickly and effectively to customer requirements in terms of developing and delivering a customized product on time and to cost. The fundamental cause of this had long resided in the inappropriate structures of the PIP within the business. Competitor companies had seen the benefits of instigating team-based product development activities based upon a CE philosophy. In order to compete successfully the company described here had to develop a structure which not only matched the best in the field but actually exceeded it. The fact that the company did indeed establish itself as a global player based upon a product development facility based in its home facility demonstrated that the new PIP matched market requirements and supported long-term growth.

Similarly, the aim of establishing a significant product service business, including the supply of 'engineered to order' spares (often requiring redesign), could only be made possible by a highly competitive PIP which ensured rapid turn-around of products. Once again, the very fact that a successful service business was established demonstrated the effectiveness of the new PIP — without it the company could not have utilized its existing processes to engineer components in a competitive manner.

Finally, the issue of retention of highly qualified engineers was another measure taken to indicate a culture of long-term improvement. Recruitment of good people was often secondary to the retention of these people. The old processes employed to develop new products had obviously failed to maintain competitiveness and this had been evident to both senior managers and those engineers involved in day-to-day design activities. As a consequence, many well qualified people left the business to find greater challenges elsewhere. The commitment to a radically improved PIP was one factor which provided significant evidence of a senior management commitment to take radical and well considered decisions to improve. Under these conditions it is undoubtedly the case that, once good people have been recruited, they will find greater job satisfaction and commit themselves to the company. Therefore the parallel activity conducted by the company of recruiting a new cohort of engineers was strongly supported by the initiatives involved in developing the new PIP.

\section{CONCLUSIONS}

The introduction of the cell-based system across the whole business proved to be highly successful in facilitating both long- and short-term improvement via a visible control system. The transparent dissemination of strategic objectives throughout the business enabled the focus of attention, at all levels, to be on those performance measures which directly contributed to 
the short- and long-term business targets related to the development and introduction of new products. The approach of employing Beer's VSM to design the interrelationships of the GA cells was shown to be highly beneficial since it ensured confidence and proved, in practice, that the new system would be robust and up-and-running in a minimum of time. The close linkage between the operational GAs, the excellence GAs and the strategic GAs ensured that the business improved within realistic resource constraints with skills and finance prioritized towards the most important projects.

The introduction of the excellence GAs was seen by the authors as adding to the VSM approach by creating a further layer to ensure that continuous improvement, aimed at new product introduction, was managed proactively. The important feature of this concept was that the excellence GAs were planned to be an integral part of the company structure and thus fitted seamlessly within the VSM. Clearly their success would not have been so great if they had been applied as an add-on after the basic structure had been developed.

The excellence GA, which instigated many improvement initiatives, proved to be the basis of the company-wide graduate training programme. It provided challenging opportunities for highly motivated individuals based around projects which were clearly aligned with the strategic objectives of the business. This had a knock-on effect across the business, where the general employment environment attracted highly qualified individuals to the company.

Clearly, and as will be found in all such situations, not everyone was convinced that the projected change would be beneficial to their own individual work experience. Some people involved in new product introduction were reluctant to change from their function-based environment and become subject to clear and unambiguous performance measures and, as has been stated earlier, the implementation was directive in nature. A participative approach at local level was welcomed but the overall framework and interrelationships of the GA cells were imposed by senior management. However, the benefits of the approach quickly became apparent as the improvements began to be accumulated. People in the company began to value the visible nature of the control system; it made their lives easier since they knew exactly what was required of them in relation to new product introduction. The one area where it could be said that residual difficulties remained was in the cross-measures system, since people were reluctant to post critical measures on the boards of other people who were their friends and on whom they were often dependent. This is inevitable in any human system and it was not seen as being beneficial to be overly directive in this area, the company believing that in time the general environment of improvement would lead individuals to see this part of the system as mutually supportive rather than as a source of potential conflict. In addition, the excellence GAs were specifically tasked that in the early days they would, as part of their role, take on some of the responsibilities associated with identifying cross-measurement issues and identifying improvement actions.

Finally, the company moved rapidly from a functional to a project-based structure with a visually clear product introduction control system based upon the transparent dissemination of strategic objectives across the complete business. The new control system was designed in such a way as to ensure immediate viability after implementation, with both short- and long-term improvements in mind. The experience of the company was such that immediate strategic objectives in terms of product cost and time to market were achieved in the short term and that many longer-term improvements were facilitated by this approach.

\section{REFERENCES}

1 Brookes, N. J. and Backhouse, C. J. Measuring the performance of product introduction. Proc. Instn Mech. Engrs, Part B, Journal of Engineering Manufacture, 1998, 212(B1), $1-11$.

2 Beer, S. Brain of the Firm, 1972 (John Wiley, Chichester).

3 Backhouse, C. J., Brookes, N. J. and Burns, N. D. Contingent approach to the application of concurrent engineering to the product introduction process. IEE Proc. A, J. Sci. Measmt Technol., 1995, 142(5), 389-394.

4 Norridge, B., Burns, N. D. and Backhouse, C. J. The 'Green Area' concept. Proc. Instn Mech. Engrs, Part B, Journal of Engineering Manufacture, 1997, 211(B3), 189-196.

5 Mintzberg, H. On Management, 1989 (Prentice-Hall, Englewood Cliffs, New Jersey).

6 Backhouse, C. J. and Brookes, N. J. (Eds) Concurrent Engineering: What's Working Where, 1996 (Gower, Aldershot).

7 Parnaby, J. The Lucas Manufacturing Engineering Handbook, 1989 (Lucas Applied Systems Limited, Solihull). 